\title{
CONFLICT RESOLUTION IN CYPRUS
}

\author{
Mehmet Ozkaya \\ Department of Management Science \\ The George Washington University
}

Abstract: In this paper, the conflict between the Turkish Cypriots and the Greek Cypriots in Cyprus is used to demonstrate the AHP approach to the conflict management. The United Nations peacekeepers have remained in Cyprus since 1964 to maintain the ceasefire lines and assist in humanitarian relief. Meanwhile, the United Nations has sponsored negotiations between the leaders of Cyprus's two mutually suspicious ethnic communities, but all efforts to reach a solution and reunify the island have thus far failed. In such a retributive ongoing conflict, the parties try to maximize both their benefits from and costs to the opponent. Using the AHP, benefit and cost hierarchies are constructed for the parties, four for each, involving actual and perceived benefits and costs of concessions.

\section{1) NATURE OF THE PROBLEM}

In terms of modern history Cyprus's three great empires were those of the Greeks, the Turks, and the British. Cyprus was part of the Byzantine Empire for more than eight centuries, beginning in the fourth century. In 1570, the Turks arrived, under the standard of the Ottoman Empire. Last came the British: in 1878, they took Cyprus "in trust" from the declining Ottomans, and in 1914 they annexed the island outright.

Until the nineteen-fifties, Cyprus was relatively quiescent. In 1955, however, the amiable relationship broke down. Archbishop Makarios, the religious leader of Greek Cypriots and the General George Grivas (a Greek citizen, though a native Cypriot) fostered a guerrilla force, known as EOKA (an acronym for the Greek), whose purpose was to free Cyprus from British rule. The goal of EOKA was not independence, however, but the realization of the old-age Hellenic dream of enosis, or union with Greece by eliminating the Turkish minority. The alarmed Turkish Cypriot minority, which had begun to abandon areas where the Greek Cypriot majorities lived, and to establish its own enclaves, responded by setting up a militant guerrilla force of its own, which was known as the Turkish Resistance Organization, or T.M.T. It was the creation of a young lawyer named Rauf Denktas.

The British realized that ruling the island had become an impossible task, and on August 16,1960 , to the dissatisfaction of both ethnic communities, a reluctant independent Republic of Cyprus was born. The new nation's constitution was written by Britain, Greece, and Turkey. All three of the former ruling powers, by then allies in NATO, retained rather extraordinary rights. The British retreated to their Sovereign Base Areas and both Greece and Turkey were permitted to establish military contingents on the island. According to the constitution, cabinet posts and seats in the legislature would be distributed in a ratio of seven to three. The Greek would elect a President, and the Turkish Cypriots, in a separate poll, would elect a Vice-President. It was an unusual way to give birth to a nation, and the two communities went on growing farther apart. At the end of 1963, when Archbishop Makarios, who was now President, proposed removing nearly all the Turkish Cypriots' constitutional safeguards, the Turkish Cypriots left the government, and never returned to it. By the summer of 1964, some twenty-five thousand Turkish Cypriots, or about one-fifth of their number, had moved into defended enclaves. Their leaders began setting up their own institutions and looking after their own affairs. 'The Greek Cypriots responded by cutting off communications and imposing an economic blockade. 
In the summer of 1974, after Cyprus had known fourteen years of an uneasy independence, marked by intercommunal strife, a Greek military dictatorship engineered the overthrow of the Cyprus government and intensified the ethnic violence[1].

In July 1974, Turkey intervened to protect its ethnic community. Today, some thirty-five thousand Turkish troops remain on Cyprus and control thirty-seven percent of its land. After the Turkish intervention, 180,000 Greek Cypriots moved to the south from the north and 60,000 Turkish Cypriots moved to the north from the south. In November 1983, the Turkish Cypriots declared their independent republic, North Cyprus Turkish Republic (N.C.T.R.), which only Turkey recognizes.

The United Nations peacekeepers first arrived in Cyprus in 1964, under a three month mandate; they have remained for over a quarter of a century. More than two thousand soldiers, from Britain, Canada, Austria, and Denmark, redeployed across the island between the Turkish and Greek Cypriots' regions. The peacekeepers' mandate is to maintain the ceasefire lines and assist in humanitarian relief. Weapons may 'only be used in self-defense. It is the United Nations' second largest and third-oldest peacekeeping force after the Middle East and Kashmir. The total bill for peacekeeping since 1964 is more than three billion dollars [2].

Since 1964, the United Nations has sponsored negotiations between the leaders of Cyprus's two mutually suspicious ethnic communities, but all efforts to reach a solution and reunify the island have thus far failed in spite of a number of proposals that, at least to U.N. negotiators and foreign diplomats, have sounded highly reasonable.

\section{2) AHP AND CONFLICT MANAGEMENT}

As Saaty and Alexander [4][3] indicated, there are three ideas involved in the AHP approach to the Conflict Management. The first is the desire of parties to punish the opponent. In a retributive conflicts, each party determines its gains in part by incurring costs to the opponent. The second is that the recommended solution to a conflict needs to have the attribute of stability to each of the parties. Third, when a conflict does not appear to have a resolution, the parties should be able to expand the set of concessions by embedding the conflict in a cooperative setting, in order to break an impasse in the narrower confines of the existing problem.

Thus, a retributive conflict model, which allows the parties to calculate their benefits from opponent's concessions and their costs for making concessions as well as their perception of opponent's benefits and costs, can be used. In a conflict resolution scenario wherein each party has a set of concessions to make, party $\mathrm{A}$, for example, calculates:

(1) the benefits it will accrue from B's concessions;

(2) its perception of the costs $B$ will pay;

(3) its costs for making concessions to $B$;

(4) its perception of the benefits to $B$ from these concessions.

For the Cyprus Conflict, for both the Turkish and Greek Cypriots communities, four hierarchies are developed to calculate the above described benefits and costs. In all, therefore, there are eight hierarchies constructed which will be explained in the following sections.

\section{3) CONCESSIONS}

\subsection{Concessions by the Turkish Cypriots:}

A list of seven concessions that can be made by the Turkish Cypriots is as follows: 


\subsubsection{Land:}

The Turkish Cypriots, whose population is approximately twenty-percent of the whole population of the island, occupy the thirty-seven percent of the land. Although Turks have agreed to make a concession, the percentage of territory that will remain under the Turkish Cypriots control could not be decided. The two sides spent more than 8 years arguing over whether it will be more than twenty-nine percent or less than twenty-nine percent.

\subsubsection{Reduce the Number of Turkish Soldiers:}

Today, around twenty-five thousand Turkish troops remain in the North Cyprus. They are considered one of the main obstacles to agreement by the Greek Cypriots and Western World; however, the troops are perceived as a vital part of the Turkish Cypriots' security system by the Turkish Cypriots.

\section{*3.1.3. Allow Greeks to Return:}

After Turkish intervention in 1974, approximately 180,000 Greek Cypriots moved south from the north. The Greek Cypriots' leaders claim that even though most of the refugees prefer not to live in a Turkish-administered zone, they must be allowed to return north and no one will accept any agreement that does not take their concerns into account [1].

\subsubsection{Allow Greeks to Return with Economic Compensation:}

The Greek Cypriots lost nearly five billion dollars' worth of business and property since 1974. Thus, in addition to the above concession of returning north, economic compensation is also included.

It should be noted that no exchange packet can contain the last two concessions at the same time since the concession given in 3.1.4. also contain the one given in 3.1.3.

\subsubsection{Give Varosha:}

Varosha is a deserted Greek Cypriot city very close to the green line on the south of N.C.T.R. territory. Among the cities deserted by both the Turkish and Greek Cypriots in 1970s, Varosha has a symbolic meaning in Western eyes. Varosha has been offered to the Greek Cypriots twice as a mini-package by the Turkish Cypriots but a settlement didn't occur.

\subsubsection{Stop Bringing New Turkish Settlers:}

During the first two years after 1974, according to the figures N.C.T.R. President Rauf Denktas disclosed, between fifteen and seventeen thousand settlers were brought in to the north. The Turks have continued to bring settlers from the mainland of Turkey, and have changed the entire demographic structure of the north. Thus, in this concession the Turkish Cypriots agree not to bring any more settlers from Turkey.

\section{1.7. Send Back Turkish Settlers:}

The Greek Cypriots' leaders insist that all the Turkish settlers who have been brought in since 1974 should be sent back to Turkey. On the other hand, Turkish leaders indicate that most of the settlers not only have married and had families on Cyprus but also have become Turkish Cypriot citizens. They also have substantial economic and political power in North Cyprus.

\subsection{Concessions by the Greek Cypriots:}

A list of five concessions that can be made by the Greek Cypriots is as foilows: 3.2.1. Stop Defense Buildup:

When Greek Cypriot President Vassiliou took office, he decided to turn the National Guard into a professional fighting force. This new emphasis on defense alarmed foreign diplomats. The buildup is certainly insufficient to enable the National Guard to confront the Turkish Army which is the second largest in NATO, but is more than sufficient to terrify the 
Turkish Cypriots. The Greek Cypriots are now spending nearly a million dollars a day for the buildup of half a million people [1].

\subsubsection{Lift Economic Embargo:}

During the sixties, when the Turkish Cypriots began setting up their own institutions and looking after their own affairs, the Greek Cypriots responded by cutting off communications and imposing an economic blockade. The Greek Cypriots insist on keeping the economic embargo as Iong as the Turkish Cypriots insist on an independent state. They believe that any step taken to lift the embargo would be tantamount to recognizing partition, to legalizing N.C.T.R.

3.2.3. Recognize the Presence of Turkish Community:

During one of the interviews, the Archbishop Chrysostomos claimed that the original Turkish Cypriots weren't even Turks. "They were Greeks, Franks, Venetians, who were forced to become Turks" [1]. The Orthodox Church of Greek Cypriots has enjoyed enormous influence as the touchstone of Greek religion, culture, and education. Its political power became even more pronounced during the seventeen years that Archbishop Makarios was both priest and President.

Besides, the Turkish Cypriots claim that the Greek Cypriots insist on denying the fact that there are two separate communities on the island and keep calling their president as the "President of Cyprus" although the Greek Cypriot government has not represented the Turkish Cypriots for the last twenty-nine years.

\subsubsection{Accept Self-Determination:}

Mr. Denktas, the President of N.C.T.R., believes that the self-determination is one of the main issues and should be accepted by the Greek Cypriots in order to get a settlement. On the other hand, the Greek Cypriots think that self-determination means secession so that it can not be accepted.

\subsubsection{Open Nicosia Airport:}

Nicosia, Cyprus's capital, which is divided into Turkish and Greek Nicosia, is a city on the green line. There is now only one crossing point between the Greek and the Turkish sectors of Nicosia, by way of the United Nations buffer zone. The Turkish Cypriots asked that the Nicosia airport which has been closed for nineteen years, be reopened jointly, under U.N. control. In return, they offered Varosha, but the Greek Cypriots did not accept it.

\section{4) APPLICATION}

As discussed in the previous section, four hierarchies should be developed to calculate the benefits and costs of concessions for each side. In this section, the conflict resolution method is explained together with accompanying calculations to illustrate how the results from several hierarchies are combined.

\subsection{The Turkish' Cypriots' Perception of Greek Cypriots' Costs of Making Concessions:}

Figure 4.1 shows the hierarchy that is used to evaluate the Turkish Cypriots' perception of Greek Cypriots' cost of making concessions. Three main objectives of Greek Cypriots are addressed during the evaluation process:

4.1.1. Political Power:

Since the declaration of independent Republic of Cyprus in 1960, the Greek Cypriots have dominated the Turkish community in the political arena. According to the constitution written in 1960 , cabinet posts and seats would be distributed in a ratio of seven to three. The president of Greek Cypriots has been continued to be as the "President of Cyprus" by the Western World although the Greek Cypriot government has not represented the Turkish Cypriots for the last 
twenty-nine years. Thus, one of the main objectives of Greek Cypriots is to maintain their political power.

FIGURE 4.1 THE TURKISH CYPRIOTS' PERCEPTION OF GREEK CYPRIOTS' COSTS OF MAKING CONCESSION

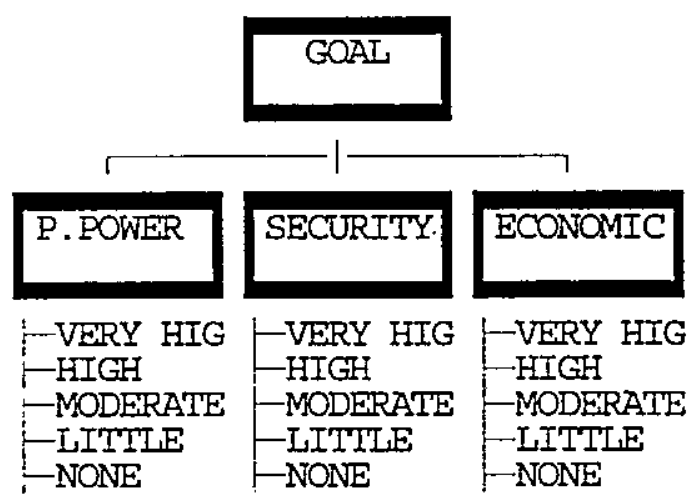

GREEK CYPRIOTS' CONCESSIONS

ECONOMIC -- ECONOMIC POWER OF THE GREEK CYPRTOTS

P.POWER -.. POLITICAI POWER OF THE GREEK CYPRIOTS

SECURITY -- SECURITY OF THE GREEK CYPRIOTS

\subsubsection{Security:}

The Greek Cypriots, by claiming that they are under the threat of the Turkish troops that are located in North Cyprus, is spending more a than a million dollar for defense buildup each year. Besides, around thirty-thousand Greek troops are remaining in South Cyprus. Thus, they consider the objective of maintaining the security as a vital one.

\subsubsection{Economic:}

The South Cyprus economy has concentrated on tourism, manufacturing and agriculture. The per-capita income in the Greek south is over seven thousand dollars a year which is more than twice of that of North Cyprus. The Greek Cypriots' another important objective is to maintain their economic power.

\subsubsection{Judgments About Objectives:}

In order to ascertain how much the concessions of the Greek Cypriots hurt them, the objectives of the Greek Cypriots should first be evaluated and prioritized. The judgments about objectives given in Table 4.1 are made numerically with the Expert Choice software. The more significant an objective is with respect to the goal, the higher is its numerical score.

\section{TABLE 4.1 COMPARISON OF THE GREEK CYPRIOTS' OBJECTIVES}

$\begin{array}{lccc} & \text { P.POWER } & \text { SECURITY } & \text { ECONOMIC } \\ \text { P.POWER } & & 1.5 & 2.5 \\ \text { SECURITY } & & & 2.0 \\ \text { ECONOMIC } & & & \end{array}$

The above judgments yield the priorities, given in Figure 4.2, that show the relative importance of each objective according to the goal:

It is believed that maintenance of their political power is the main objective of the Greek Cypriots and is thus much more important than the other objectives. The second most important concern of the Greek Cypriots is to maintain their security, then maintaining the economic power comes as the least important one. 


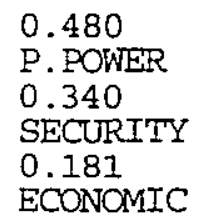

\subsubsection{Ratings:}

The third level of the hierarchy in Figure 4.1 is formed by the intensities that will be used to rate the concessions. The preferability of each intensity can be obtained by pairwise comparisons. The judgments about the intensities are made numerically and shown in Table 4.2.

TABLE 4.2 JUDGMENTS ABOUT INTENSITIES

$\begin{array}{lccccc} & \text { VERY HIGH } & \text { HIGH } & \text { MODERATE } & \text { LITTLE } & \text { V.LITT } \\ \text { VERY HIGH } & & 3.0 & 4.0 & 7.0 & 9.0 \\ \text { HIGH } & & & 4.0 & 4.0 & 9.0 \\ \text { MODERATE } & & & & 4.0 & 9.0 \\ \text { LITTLE } & & & & & 9.0 \\ \text { V.LITT } & & & & & \end{array}$

The following relative priorities for the intensities are derived from the above judgments:

FIGURE 4.3 PRIORITIES OF THE INTENSITIES

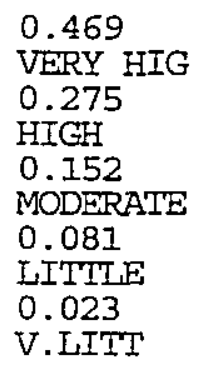

The bottom level of the hierarchy in Figure 4.1 is formed by the concessions of the Greek Cypriots which were explained in Section 3.2. The Turkish Cypriots' perception of Greek Cypriots' costs of making concessions can be found by rating the effect of each concession on the objectives of the Greek Cypriots by using the intensities as shown in Table 4.3.

TABLE 4.3 RATINGS OF THE GREEK CYPRIOTS' CONCESSIONS

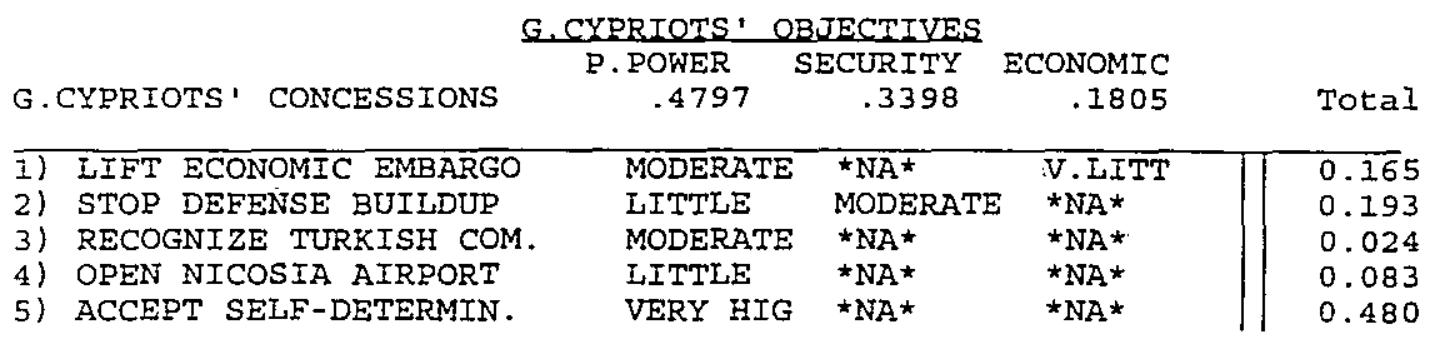


At the top of the Table 4.3, the objectives of the Greek Cypriots with their relative importance are given. The rows 1 to 5 contain the verbal ratings next to the each concession. For example, the second row contains the Greek Cypriots' concession of "Stop Defense Buildup". The Turkish Cypriots estimate that this concession has a little effect on the Greek Cypriots' objective of "Maintaining Political Power", moderate effect on the "Security", and no effect on the "Economic" (it is represented by *NA* which means not applicable).

These verbally expressed ratings are converted to the numerical values by using the relative importance of each objective and the priorities of the intensities. The right most column shows the overall numerical results of the ratings which represent the Turkish Cypriots' perception of the Greek Cypriots' costs of making concession.

\subsection{The Turkish Cypriots' Perception of its Benefits from Greek Cypriots' Concessions:}

Figure 4.4 shows the hierarchy that is used to evaluate the Turkish Cypriots' perception of its benefits from Greek Cypriots' concessions.

FIGURE 4.4 THE TURKISH CYPRIOTS' PERCEPTION OF ITS BENEFITS FROM GREEK'S CONCESSION

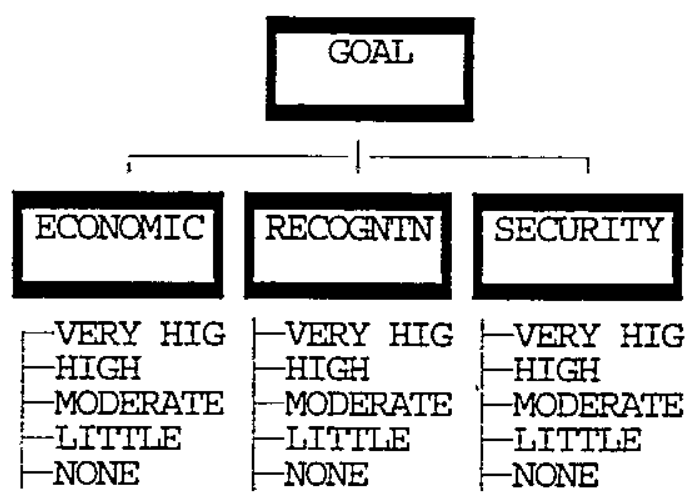

GREEK CYPRIOTS' CONCESSIONS

ECONOMIC -- BRIDGING THE ECONOMIC GAB BEIWEEN NORTH AND SOUTH

RECOGNIN -.- RECOGNITION OF TURKISH REPUBLIC

SECURITY --- SECURTTY OF TURKISH CYPRIOTS

Three main objectives of Turkish Cypriots are addressed during evaluation process of concessions:

4.2.1. Economic:

The North Cyprus economy has concentrated on tourism, and agriculture. The per-capita income is around two thousand three hundred dollars. The North Cyprus has been under the economic embargo of Southern Cyprus for more than twenty-nine years. One of the main objectives of the Turkish Cypriots is to bridge the economic gab between the North and South.

4.2.2. Recognition:

After the Turkish Cypriots left the Cyprus Government in 1963, they began setting up their own institutions and they declared their own independent republic in 1983 which only Turkey recognizes. Thus, the main objective of the Turkish Cypriots is to get their selfdetermination right and be recognized not only by those several states which are ready to recognize N.C.T.R. but also by the rest of the world. 


\subsubsection{Security:}

The secure life which came with the Turkish intervention after a fourteen year long ethnic violence convinced the Turkish Cypriots that their security is possible only with a bizonal federation under the Turkish guarantor power. On the other hand, the Greek Cypriots' tremendous spending for the defense buildup has been terrifying the Turkish Cypriots. Thus, maintaining the security is one of the main objectives of the Turkish Cypriots.

4.2.4. Judgments About Objectives:

The relative importance of each objective with respect to the overall goal can be obtained by pairwise comparisons as explained in Section 4.1.4. The judgments about objectives yield the following priorities:

FIGURE 4.5 PRIORITIES OF THE OBJECTIVES

\subsection{5}

ECONOMIC

0.498

RECOGNTN

0.217

SECURITY

It is believed that the recognition is the main objective of the Turkish Cypriots and is thus more important than the other objectives. The second most important concern of the Turkish Cypriots is to bridge the economic gab. The "Security" is the least important one since the Turkish Cypriots have been living in secure since 1974.

4.2.5. Ratings:

The Turkish Cypriots' perception of its benefits from Greek Cypriots' concessions can be found by rating the effects of each concession on the objectives of the Turkish Cypriots by using the intensities as shown in the following table:

TABLE 4.4 RATINGS OF THE GREEK CYPRIOTS' CONCESSIONS

\begin{tabular}{|c|c|c|c|c|}
\hline \multirow[b]{2}{*}{ CONCESSIONS } & \multicolumn{3}{|c|}{ T.CYPRIOTS: OBIECTIVES } & \multirow[b]{2}{*}{ Total } \\
\hline & $\begin{array}{l}\text { ECONOMIC } \\
.3035\end{array}$ & $\begin{array}{l}\text { RECOGNTN } \\
.5190\end{array}$ & $\begin{array}{l}\text { SECURITY } \\
.1775\end{array}$ & \\
\hline LIFT ECONOMIC EMBARGO & HIGH & MODERATE & $\star N A *$ & 0.347 \\
\hline STOP DEFENSE BUILDUP & *NA * & *NA* & HIGH & 0.104 \\
\hline RECOGNIZE TURKISH COM. & $\star N A *$ & MODERATE & $\star N A *$ & 0.169 \\
\hline OPEN NICOSIA AIRPORT & V.IITT & HIGH & $\star N A *$ & 0.320 \\
\hline ACCEPT SELF-DETERMIN. & $\star N A *$ & VERY HIGH & V.LITT & 0.528 \\
\hline
\end{tabular}

The right most column shows the overall numerical results of the judgments which represent the Turkish Cypriots' perception of its benefit from Greek Cypriots' concessions. hierarchies.

In the following section, we are going to show how to combine the results of eight

\subsection{Combining the Results:}

In negotiations, each party not only calculates the incremental benefits it gets, but also the costs to its opponent. The more of either, the greater is the total gain. Thus, the total gain is the product of the benefits to the party and the costs to the opponent. Each side must also calculate what it estimates to be the opponent's gain as a product of benefits to the opponent and 
costs to itself, and make sure that the ratio of its gain to the opponent's gain, which it considered as a loss, is not less that what the opponent is perceived to get.

In Sections 4.1 and 4.2, the Greek Cypriots' costs and the Turkish Cypriots' benefits from the Greek Cypriots' concessions were found from the Turkish Cypriots' percéptive: Table 4.5 summarizes our findings:

TABLE 4.5 THE TURKISH CYPRIOTS' PERCEPTION OF ITS TOTAL GAINS FROM THE GREEK CYPRIOTS' CONCESSIONS

\begin{tabular}{llcc} 
G.CYPRIOTS' CONCESSIONS & $\begin{array}{l}\text { GREEKS' } \\
\text { COSTS }\end{array}$ & $\begin{array}{c}\text { TURKS' } \\
\text { BENEEITS }\end{array}$ & $\begin{array}{c}\text { TOTAI T. CYPRIOTS ' } \\
\text { GAINS } \\
\text { (GC 'TB) }\end{array}$ \\
\hline 1) IIFT ECONOMIC EMBARGO & 0.165 & 0.347 & 0.057 \\
2) STOP DEFENSE BUIIDDUP & 0.193 & 0.104 & 0.020 \\
3) RECOGNIZE TURKISH COM. & 0.024 & 0.169 & 0.004 \\
4) OPEN NICOSIA AIRPORT & 0.083 & 0.320 & 0.027 \\
5) ACCEPT SELF-DETERMIN. & 0.480 & 0.528 & 0.253
\end{tabular}

The right most column above, which is the product of columns 2 and 3 , shows the total Turkish Cypriots' gains. That is, the results of two models which were developed in the previous sections are multiplied to calculate the Turkish Cypriots' perception of its total gains from the Greek Cypriots' concessions.

In a similar way, the Turkish Cypriots' perception of its total losses of making concession was found. Table 4.6 shows the final results:

TABLE 4.6 THE TURKISH CYPRIOTS' PERCEPTION OF ITS TOTAL LOSSES OF MAKING CONCESSION

\begin{tabular}{llcc} 
T.CYPRIOTS ' CONCESSIONS & $\begin{array}{c}\text { TURKS' } \\
\text { COSTS }\end{array}$ & $\begin{array}{c}\text { GREEKS' } \\
\text { BENEEITS }\end{array}$ & $\begin{array}{c}\text { TOTAL T. CYPRIOTS ' } \\
\text { IOSSES }\left(T \text { TGB }^{\star}\right.\end{array}$ \\
\hline I) GIVE IAND & 0.274 & 0.477 & 0.131 \\
2) REFUGEES RETURN & 0.177 & 0.102 & 0.018 \\
3) REFUGEES ECONOMIC COMP. & 0.225 & 0.174 & 0.040 \\
4) REDUCE T. SOLDIERS & 0.227 & 0.270 & 0.061 \\
5) STOP SETTLERS & 0.028 & 0.026 & 0.001 \\
6) SEND SETTLERS BACK & 0.202 & 0.079 & 0.016 \\
7) GIVE VAROSHA & 0.102 & 0.139 & 0.014
\end{tabular}

So far, results of the four models are combined to calculate the Turkish Cypriots' total gains from the Greek Cypriots' concessions and their total losses of making concession. These final total gains and losses are used in deciding whether they should make a concession in return for a concession by the Greek Cypriots. The Turkish Cypriots want their total gains to be greater than their total losses for an exchange.

For instance, the total Turkish Cypriots' losses from its concession "REDUCE TURKISH SOLDIERS" have the value of 0.061 (Table 4.6, Row 4, Column 4). The Turkish Cypriots will agree to make this concession in exchange for any concession by the Greek Cypriots which will give the Turkish Cypriots gains of greater than 0.061 . The only Greek concession satisfying this criterion (from Table 4.5, Row 5, Column 4) is the "ACCEPT SELF-DETERMINATION" which gives the total gains of 0.253 to the Turkish Cypriots. Thus, the Turkish Cypriots will accept to reduce the number of the Turkish Soldiers in exchange for the Greek Cypriots' concession of accepting Turkish Self-Determination since their total gains are greater than their losses. The Turkish Cypriots' perception of this exchange is given below in Table 4.7: 
TABLE 4.7 THE TURKISH CYPRIOTS' PERCEPTION

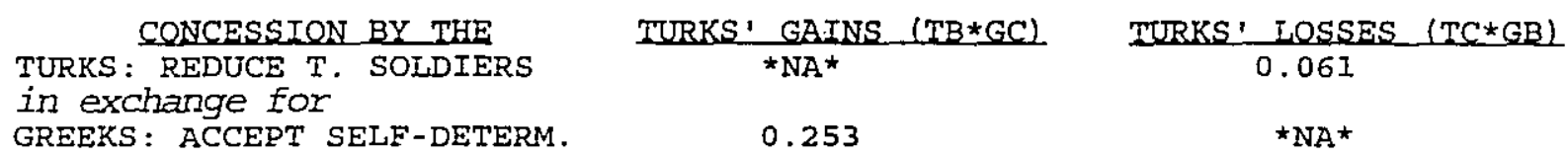

Another possible approach to decide whether or not the Turkish Cypriots should accept this exchange is to calculate their gains/losses ratio [4]. In a negotiation process, each party wants its ratio to be greater than unity or not less than what the opponent is perceived to get. The gains/losses ratio of the above exchange for the Turkish Cypriots is $0.253 / 0.061$ which is equal to 4.14. Since their gains/losses ratio is greater than unity, we can conclude that the Turkish Cypriots favor this exchange.

But the Greek Cypriots will agree to make the concession of "ACCEPT SELFDETERMINATION" if and only if their total losses for making this concession are less than their total gains from the Turkish Cypriots' concession. Following the same procedure, the Greek Cypriots' perception of this exchange is found as follows:

TABLE 4.8 THE GREEK CYPRIOTS' PERCEPTION

CONCESSION BY THE

GREEKS: ACCEPT SELF-DETERM.

in exchange for

TURKS: REDUCE T.SOLDIERS

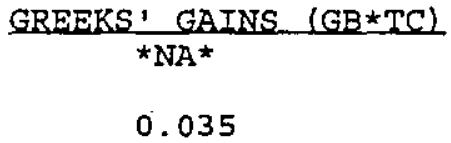

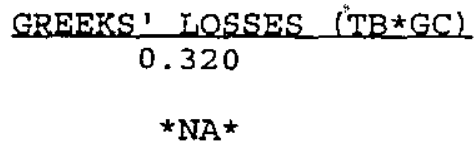

GREEKS 1 IOSSES (TB*GC)

*NA*

The gains/losses ratio of the above exchange for the Greek Cypriots is $0.035 / 0.320$ which is equal to 0.109. Since their gains/losses ratio is less than one, the Greek Cypriots do not favor this exchange. As the result of the analysis of this particular exchange scenario, we can conclude that while the Turkish Cypriots favor this exchange (since their gains/losses ratio is greater than one), the Greek Cypriots would not accept it (since their gains/losses ratio is less than one).

\subsection{Expanding The Analysis:}

In section 4.3, an example for the process of exchanging single concessions is demonstrated. The same kind of reasoning can be applied to negotiating packages of concessions [4]. In this case, since each party considers more than one concession, the gains/losses ratio for each party should be calculated in the following way:

GAINS/LOSSES RATIO = Sum of Total Gains / Sum of Total Losses

As an example, lets consider the exchange scenario which includes "STOP DEFENSE BUILDUP" and "OPEN NICOSIA AIRPORT" as the Greek Cypriots' concessions and "REDUCE TURKISH SOLDIERS", "SEND SETTLERS BACK", "GIVE VAROSHA" as the Turkish Cypriots' concessions.

Table 4.9 shows the sum of total gains of the Greek Cypriots and the sum of total losses of Turkish Cypriots from the Turkish Cypriots' concessions:

TABLE 4.9 TOTAL GAINS OF GREEK CYPRIOTS AND TOTAL LOSSES OF TURKISH CYPRIOTS

T.CYPRIOTS' CONCESSIONS REDUCE TURKISH SOLDIERS SEND SETTLERS BACK

GIVE VAROSHA

GREEK'S GAINS (GB*TC)
0.035
0.013
0.001
TOTAL: $\quad 0.049$

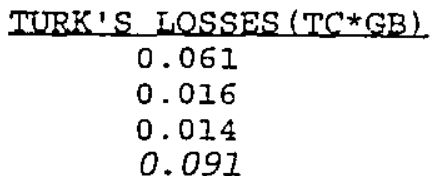


Table 4.10 shows the sum of total losses of the Greek Cypriots and the sum of total gains of Turkish Cypriots. from the Greek Cypriots' concessions:

TABLE 4.10 TOTAL LOSSES OF GREEK CYPRIOTS AND TOTAL GAINS OF TURKISH CYPRIOTS

G.CYPRIOTS' CONCESSIONS

STOP DEFENSE BUILDUP

OPEN NICOSIA AIRPORT
GREEK'S IOSSES (GC*TB)

0.039

0.033

TOTAL: $\quad 0.072$

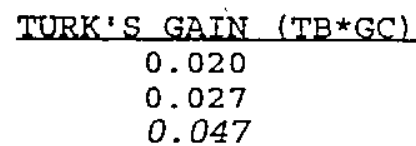

The gains/losses ratio of this exchange packet for the Greek Cypriots can be found by: GAINS/LOSSES RATIO $=0.049 / 0.072=0.680$

Similarly, the gains/losses ratio of this exchange packet for the Turkish Cypriots: GAINS/LOSSES RATIO $=0.047 / 0.091=0.516$

For this particular exchange scenario, none of the parties' gains/losses ratio is greater than one. Thus, this exchange is not favored by any of the sides.

In order to find an exchange packet that is acceptable to both parties, all the possible combinations of concessions for each party should be considered. The software that is used during this analysis is able to evaluate all the possible exchange scenarios that includes up to three concessions. Unfortunately, the results of synthesis show that there is no combination of concessions that is acceptable to the both parties (according to our judgments).

\section{5) CONCLUSION}

As we emphasized in the previous section, the results of our synthesis show that there is no combination of concessions that is acceptable to both parties.

This may be because of our judgments about not only the importance of objectives of the parties but also the impacts of concessions on the objectives. If the synthesis is redone with the judgments of bureaucrats from each side, the outcome may be different from our findings.

Another possible reason may be the limited capability of the software that is used for the synthesis. If we were able to check all the possible sets of concessions (remember that the scenarios that includes up to three concessions were evaluated) we would probably end up with tradeoffs that are acceptable to both parties.

In general, the role of the negotiator gets more critical when no exchange scenario acceptable to the both parties is found. In this situation, the negotiator should ensure that neither of the parties' gains/losses ratio is perceived by the other party to be much greater than its own. Specifically, in the example discussed in section 4.4, the negotiator must devise some means of making the gains/losses ratio of the Turkish Cypriots comparable with that of the Greek Cypriots. This can be done making changes either in the exchange packet or in the hierarchies.

The changes in the exchange packet can be done by adding new concessions to or dropping some of the concessions from the exchange packet to bring the two ratios closer so that at least a starting point for the further negotiation process can be found. The major benefit of the calculation of gains and losses for the various scenarios for the negotiator is to be able to see the disparity between them. If the disparity is too large, the negotiator might ask for greater concessions from the stronger party.

If no starting point can be found by modifying alternate exchange scenarios, the hierarchies that are used for evaluation process can be modified. This can be done by asking each side for new concessions that have not been considered before or dividing the present concessions into sub-concessions so that new exchange scenarios can be developed. For example, 
the Turkish Cypriots concession of "Give Land" can be further divided into sub-concessions such as "Give Land; The Turkish Cypriots Control 33\% of the Island", "Give Land; The Turkish Cypriots Control 30\% of the Island", and "Give Land; The Turkish Cypriots Control 29\% of the Island", etc. Similarly, the Greek Cypriots' concession of "Lift Economic Embargo" can be divided into sub-concessions. These adjustments in the concessions not only create new exchange scenarios but also diversify the adverse impacts of one main concession to new sub-concessions. For example, although the Greek Cypriots do not accept to lift the whole economic embargo, they may consider to lift the embargo for particular items.

Unfortunately, our findings do not yield any tradeoff that are acceptable to both parties. But it is believed that this study can be a good starting point for the further analysis of the problem.

On the other hand, what our resuits really show is the fact that the conflict in Cyprus is an extremely complicated one in which the emotions and the memories of the past experiences play an important role for both sides in decision making. Considering the United Nations' efforts to find a solution since 1964 (that have thus far failed), it won't be unfair to conclude that it will take time to find stable solutions to the problems of the Cypriots.

\section{REFERENCES}

[1] Mary Anne Weaver, Report Erom Cyprus, The New Yorker, 1991, v.66, p.65-81

[2] Robert McDonald, Guarding the Line, Maclean's, 1989, v.102, p.24

[3] Thomas L.Saaty, Jayce M.Alexander, A New Logic to Resolve Conflicts: The Analytic Hierarchy Process, 1987, p.253-322

[4] Thomas L.Saaty, The Analytic Hierarchy Process In Conflict Management, The International Journal of Conflict Management, 1990, v.1, n.1, p.47-68

[5] Council Calls for Completion of 'Set of Ideas' for Agreementon Cyprus, UN Chronicle, 1992 , v.29, p.70

[6] Cooperation Urged to Resolve Qutstanding Issues Over Cyprus, UN Chronicle, 1991, v.28, p. 25

[7] Thomas L.Saaty, Decision Making for Leaders, RWS Publications, 1990 